\title{
The Legislative Push to Mandate Rules-Based Monetary Policymaking in the US: The Latest Salvo in the Long-Running "Rules versus Discretion" Debate
}

\author{
Vivekanand Jayakumar \\ Economics Department, University of Tampa, Tampa, FL, USA \\ Email: vjayakumar@ut.edu
}

How to cite this paper: Jayakumar, V. (2016) The Legislative Push to Mandate Rules-Based Monetary Policymaking in the US: The Latest Salvo in the Long-Running "Rules versus Discretion" Debate. Theoretical Economics Letters, 6, 1315-1336. http://dx.doi.org/10.4236/tel.2016.66122

Received: November 16, 2016 Accepted: December 23, 2016 Published: December 26, 2016

Copyright $\odot 2016$ by author and Scientific Research Publishing Inc. This work is licensed under the Creative Commons Attribution International License (CC BY 4.0).

http://creativecommons.org/licenses/by/4.0/ (c) (i) Open Access

\begin{abstract}
US Congressional leaders have recently proposed legislation aimed at forcing the Federal Reserve to implement an instrument rule based monetary policy regime. The avowed rationale is to increase transparency and reduce uncertainty associated with monetary policymaking, and to impose constraints on the US central bank. The proposed legislation would require the Federal Reserve to adopt an interest rate setting rule, preferably a rule based on the standard Taylor Rule. This article examines the theoretical rationale for considering monetary policy rules and provides a critique of the move to legislate the adoption of interest rate setting rules in the US. Specifically, the challenges that the Federal Reserve would encounter if it were required to follow an instrument rule, and the shortcomings of any monetary regime based on the standard Taylor Rule, are detailed in this study. This article also considers the merits of basing a monetary policy regime on a targeting rule instead of an instrument rule, and argues that US policymakers would be better served if they shift their focus towards establishing a clearly defined nominal GDP targeting rule and abandon their efforts to impose operational constraints on the Federal Reserve.
\end{abstract}

\section{Keywords}

Monetary Policy, Taylor Rule, Equilibrium Real Interest Rate

\section{Introduction}

Impetus towards formally establishing monetary policy rules was provided by recent US Congressional proposals (such as H.R. 3189: The Fed Oversight Reform and Modernization (FORM) Act of 2015 and H.R. 5983: Financial CHOICE Act of 2016). These 
proposals advocate placing constraints on the Federal Reserve by establishing a set of guidelines for the central bank to follow [1]. Such attempts to prescribe rules-based monetary policymaking are backed by key members of the US House of Representatives, who are especially upset over what they perceive as excessively interventionist policymaking by the Federal Reserve in the aftermath of the financial crisis. For instance, Jeb Hensarling, Chairman of the House Financial Services Committee, wrote the following in a Wall Street Journal Op-Ed [2]: "Since the 2008 financial crisis, the Federal Reserve has morphed into a government institution whose unconventional activities and vastly expanded powers would scarcely be recognized by drafters of the original legislation that created it. Regrettably, commensurate transparency and accountability have not followed. ... [Monetary policy] uncertainty is a significant cause of businesses' hoarding cash and postponing capital investments, and of community banks' conserving capital and reducing lending."

The push to restrain central bankers, especially by demanding that they pursue some sort of an explicit monetary policy rule, is not a new phenomenon. In fact, the so-called "rules versus discretion" debate has a long history in the context of monetary policymaking. Fundamentally, there exists a dilemma between the desire to insulate central banks from political influence (which requires a high degree of central bank independence) and a need to hold an independent central bank accountable to legislators and the public [3] [4]. Current generation of central bankers and monetary economists was influenced by the seminal work of Kydland and Prescott [5], who considered the challenges faced by central banks concerned with both curbing inflation and stimulating the economy. Kydland and Prescott [5] emphasized the "time inconsistency problem", which highlights the possibility that policymakers will be tempted to promote economic welfare (higher output or lower unemployment) by publicly broadcasting one thing and then doing something else after people have made their decisions based on the initial announcement. Inconsistent policy action in a world of sequential policymaking will lead to central bankers facing a credibility problem, especially in the absence of clearly established rules or credible commitment mechanisms. The influential Barro-Gordon model [6] reinforced concerns by theoretically demonstrating that monetary authorities may suffer from an inherent inflation bias when they covet stable prices and yet desire (independently or under political pressure) to reach ambitious output or employment targets.

Proponents of rules-based policymaking in the US are motivated by a desire to limit the degree of operational freedom that monetary authorities currently enjoy [7]. They also hope to ensure greater public and market clarity in the future by reducing the uncertainty associated with the timing and direction of Federal Reserve policy actions. A critical goal of the 2015 FORM Act and the 2016 Financial CHOICE Act is to force the US central bank to adhere to a clear-cut policy interest rate setting model, preferably, one that is based on the Taylor Rule framework. Stanford economist John Taylor introduced his eponymous rule in 1993 [8]. The standard version of Taylor Rule is a simple numerical formula that relates the Federal Reserve's target for the federal funds rate 
to the underlying state of economy-captured via an inflation gap (difference between the actual inflation rate and the target inflation rate) and an output gap (difference between actual output and trend or potential output). Many current and former central bankers are dismayed by the proposed legislation [9] [10]. Opponents of rules-based policymaking are concerned that, without broad discretion, the ability of the Federal Reserve to deal with a complex and ever-changing economy may be significantly diminished [11].

Broadly, it can be argued that the quest for an appropriate nominal anchor lies at the center of the monetary rules debate. The present-day debate surrounding the selection of a nominal anchor revolves around the choice between a targeting rule/goal mandate and an instrument rule/operational mandate. In the past, dalliances with exchange rate targeting - the gold standard era (roughly 1870-1913) and the Bretton Woods System era (1945-1971) - proved to be major disappointments. It has been argued that the monetary straitjacket imposed on central banks (via the requirement that policy be centered on maintaining an exchange rate/commodity price peg) affected their ability to set policy based on domestic economic conditions, and, consequently, monetary policy was unable to engage effectively in counter-cyclical actions [12]. In the postBretton Woods era, the general theoretical consensus has been that monetary regimes based on a targeting rule or goal mandate (clear specification of objectives/goals for central banks to target-such as the adoption of an inflation or price-level targeting or a nominal GDP targeting policy regime) are more effective than one based on an instrument rule or operational mandate (such as the Taylor Rule, which limit the central bank to pursuing policy interest rate setting in a somewhat mechanical manner) [13] [14]. McCallum and Nelson [15], however, note that the theoretical case for favoring targeting rule/goal mandate over instrument rule/operational mandate is not as clear cut.

This article contributes to the ongoing debate on the efficacy of monetary rules and the selection of an appropriate nominal anchor in multiple ways. First, it considers the historical and theoretical arguments related to rules-based monetary policymaking, and then provides a critique of the move to legislate the adoption of interest rate setting rules in America. Specifically, the challenges that the Federal Reserve would encounter if it were required to follow an instrument rule (that is, set interest rates per the Taylor Rule, as favored by US Congressional leaders), and the shortcomings of a monetary regime based on the standard Taylor Rule, are detailed in the article and forms the core contribution of this study.

Second, the article considers the theoretical arguments for favoring a targeting rule based monetary regime over an instrument rule based monetary regime. Following an appraisal of the three most widely discussed targeting rule approaches (inflation targeting, price-level targeting and nominal GDP targeting), this study makes the case that the US will be better served by adopting a nominal GDP targeting rule rather than the proposed Taylor Rule type instrument rule. The ability to deal with demand and supply shocks more effectively, and, given recent events, the potential to limit the size and 
scope of asset bubbles are particularly attractive features of a nominal GDP targeting based monetary regime. This article also highlights the fact that inflation targeting regimes (quite popular since 1990 and the preferred regime in central banking circles) failed to effectively deal with the dramatic growth of asset bubbles in the pre-crisis era (before 2007). Inflation targeting regimes have also proven to be woefully inadequate in dealing with the persistently low inflation and subpar growth observed in the post-crisis period.

The rest of the paper is organized as follows: Section 2 discusses the historical and theoretical aspects related to rules-based monetary policymaking; Section 3 provides a thorough critique of the standard Taylor Rule and discusses the practical challenges of implementing an instrument rule monetary regime based on the Taylor Rule; Section 4 examines the benefits of adopting a targeting rule/goal mandate based monetary regime instead of an instrument rule/operation mandate based monetary regime, and evaluates the relative merits of the three leading targeting rule contenders-inflation targeting, price-level targeting and nominal GDP targeting; and, finally, Section 5 concludes with the argument that the US would be better served if Congressional leaders focused on mandating that the Federal Reserve follow a nominal GDP targeting regime instead of trying to force the central bank to adopt a Taylor Rule type interest rate setting regime.

\section{Optimal Monetary Policy Rules-Historical and Theoretical Considerations}

As far back as 1898 (the year when the great Swedish economist Knut Wicksell's seminal contribution Interest and Prices was published in its original German version as Geldzins und Güterpreise), there were discussions about the appropriate monetary rule for central bankers. Wicksell [16] emphasized the distinction between the "interest on money", which referred to the market or financial interest rate that borrowers pay, and the natural rate of interest (or the "profit on capital"), which referred to the real return on capital. Wicksell argued that the banking system or the central bank should aim to keep the market interest rate in line with the natural rate of interest to maintain price stability. He suggested the following rule: "So long as prices remain unaltered, the banks' rate of interest is to remain unaltered. If prices rise, the rate of interest is to be raised; and the prices fall, the rate of interest is to be lowered; and the rate of interest is henceforth to be maintained at its new level until a further movement of prices calls for a further change in one direction or the other" ([16], p. 189).

The "rules versus discretion" debate was also influenced by such $20^{\text {th }}$ century stalwarts as Frederic von Hayek and Milton Friedman. Hayek [17] proposed a constant money supply rule almost ninety years ago, that could be considered a precursor to today's much discussed nominal GDP/income targeting proposals [18]. Hayek's monetary rule was distinct in that its proponent was critical of attempts to achieve price stability. Hayek [17] instead highlighted the destabilizing effects of activist monetary policy that counteracted productivity shocks-in a competitive setting, he argued that monetary interventions may lead to distortions and maladjustments when central 
banks actions affected the evolution of relative prices and expectations of market participants and prevented needed price corrections following both positive and negative productivity shocks. White [19] provides a critique of Hayek's early opposition to price-level stabilization.

Friedman [20] put forth the $k$-percent money growth rule that gave rise to monetarism, which had its heyday in the 1970s. Friedman ([20], p. 93) suggested that the Federal Reserve should increase the money stock "at a fixed rate year-in and year-out without any variation in the rate of increase to meet cyclical needs". Monetarist-type proposals to corral central banks were often based on concerns that attempts by policymakers to fine-tune the real economy were fraught with danger especially given our limited understanding of the short-run dynamics of monetary actions and its purported effects on the real economy. Financial liberalization and technological breakthroughs undermined the relationship between monetary aggregates and key macroeconomic variables, and ultimately doomed monetarism.

More recently, the dominant theoretical approach to modelling central bank behavior has been via the application of optimization techniques to clearly defined monetary policy reaction functions. The classic Barro-Gordon model [6] provides a theoretic rationale for instituting a rules-based approach to monetary policymaking to overcome time-inconsistency problems. Leading monetary theorists, such as Michael Woodford and Lars Svensson of Princeton University, laid the theoretical foundations for considering optimal monetary policy and rules-based policymaking by developing a framework based on the mainstream New-Keynesian (NK) models [21] [22].

The simple framework discussed below highlights the theoretic rationale underlying the Taylor Rule (for a rigorous consideration of micro-founded modeling of interest rate rules and optimal monetary policy, see [21] [23]). The basic building blocks are the pair of standard log-linear functions depicting a forward-looking IS equation (Equation (1)) and the New-Keynesian Phillips Curve equation (Equation (2)). Additionally, the Fisher equation ((Equation (3))) provides the link between real interest rates and nominal interest rates:

$$
\begin{gathered}
y_{t}=E_{t} y_{t+1}-\sigma\left(i_{t}-E_{t} \pi_{t+1}-r^{n}\right) \\
\pi_{t}=E_{t} \pi_{t+1}+\lambda\left(y_{t}-y^{n}\right)+\varepsilon_{t} \\
r_{t}=i_{t}-E_{t} \pi_{t+1}
\end{gathered}
$$

The exogenously determined potential output level is given by $y^{n}$ and the equilibrium real interest rate (or the exogenously determined Wicksellian natural rate of interest) is given by $r^{n}$. Note that $\left(y_{t}-y^{n}\right)$ refers to the output gap (the log difference between actual output and potential output), and $\pi_{t}$ refers to the inflation rate in period $t$. The operator $E_{t}$ represents expectation formed in period $t$, and $\sigma$ and $\lambda$ are constant coefficients. Also, $\varepsilon_{t}$ is a random supply shock term with mean zero $\left(\varepsilon_{t}\right.$ captures potential cost-push price shocks). Finally, $r_{t}$ refers to the real interest rate and $i_{t}$ refers to the nominal interest rate (in period $t$ ).

Assume that the central bank's loss minimization function is given by: 


$$
L_{t}=\beta\left(\pi_{t}-\pi^{*}\right)^{2}+\left(y_{t}-y^{*}\right)^{2}
$$

In the above loss function, $\beta$ captures the weight placed on inflation stabilization relative to output stabilization (note: $\beta>0$ ). The central bank's inflation target is given by $\pi^{*}$ and its output target is given by $y^{*}$. It is worth noting that the selection of a specific loss function is a subjective decision (Equation (4) represents a common quadratic loss function where losses result from inflation or output being away from their respective targets) and to some extent depends on monetary policymakers' objectives and value judgments.

The optimization problem requires the minimization of Equation (4) subject to Equation (2). We can first rewrite Equation (4) as:

$$
L_{t}=\beta\left(\pi_{t}-\pi^{*}\right)^{2}+\left(\left[\frac{1}{\lambda}\left(\pi_{t}-E_{t} \pi_{t+1}-\varepsilon_{t}\right)+y^{n}\right]-y^{*}\right)^{2}
$$

The first order condition is given by:

$$
\frac{\partial L_{t}}{\partial \pi_{t}}=2 \beta\left(\pi_{t}-\pi^{*}\right)+\frac{2}{\lambda}\left(\left[\frac{1}{\lambda}\left(\pi_{t}-E_{t} \pi_{t+1}-\varepsilon_{t}\right)+y^{n}\right]-y^{*}\right)=0
$$

Solving Equation (6) and resubstituting for the output term, we get the following optimality condition:

$$
\begin{aligned}
& \pi_{t}=\pi^{*}-\frac{1}{\lambda \beta}\left(y_{t}-y^{*}\right) \\
& y_{t}=y^{*}-\lambda \beta\left(\pi_{t}-\pi^{*}\right)
\end{aligned}
$$

Per Equation (7), if the central bank sets the output target $\left(y^{*}\right)$ above current output, then actual inflation will exceed the inflation target $\left(\pi^{*}\right)$. Suppose that the central bank sets its output target at the potential output level. Then $\left(7^{\prime}\right)$ can be rewritten as:

$$
y_{t}-y^{n}=-\lambda \beta\left(\pi_{t}-\pi^{*}\right)
$$

Additionally, under rational expectations, with central bank credibility, inflation expectation is given by (from Equation (7)):

$$
E_{t+1} \pi_{t}=\pi^{*}=\pi_{t}+\frac{1}{\lambda \beta}\left(y_{t}-y^{n}\right)
$$

We can rewrite Equation (1) as follows:

$$
i_{t}=r^{n}+E_{t} \pi_{t+1}-\frac{1}{\sigma}\left(y_{t}-E_{t} y_{t+1}\right)
$$

Under rational expectations (and assuming the central bank sets its output target at the potential output level), $E_{t} y_{t+1}=y^{*}=y^{n}$. Hence, we can rewrite (10) as

$$
i_{t}=r^{n}+E_{t} \pi_{t+1}-\frac{1}{\sigma}\left(y_{t}-y^{n}\right)
$$

Substituting (8) and (9) into (11) yields:

$$
i_{t}=r^{n}+\pi_{t}+\frac{1}{\lambda \beta}\left(y_{t}-y^{n}\right)+\frac{\lambda \beta}{\sigma}\left(\pi_{t}-\pi^{*}\right)
$$


If we denote $\phi_{y}=\frac{1}{\lambda \beta}$ and $\phi_{\pi}=\frac{\lambda \beta}{\sigma}$, then (10) can rewritten as:

$$
i_{t}=r^{n}+\pi_{t}+\phi_{\pi}\left(\pi_{t}-\pi^{*}\right)+\phi_{y}\left(y_{t}-y^{n}\right)
$$

The above equation has the familiar Taylor Rule type rate setting framework (see Equation (14)). Central banks set the nominal policy interest rate based on both the output gap and the inflation gap. Observe that when actual inflation equals the target rate and actual output equals the potential output, the nominal policy rate equals the equilibrium real interest rate plus the inflation target rate $\left(r^{n}+\pi^{*}\right.$ is usually referred to as the neutral policy interest rate).

\section{Taylor Rule Based Monetary Policy Regime-Implementation Challenges}

Taylor [8] proposed a simple policy rule that quickly gained widespread acceptance as a reasonable framework for analyzing policy rate setting decisions of central banks. The standard Taylor Rule as proposed by Taylor [8] [24] can be expressed as follows (with equal weights placed on the output gap and inflation gap):

$$
i_{t}=2 \%+\pi_{t}+0.5\left(\pi_{t}-2 \%\right)+0.5\left(y_{t}-y^{n}\right)
$$

The policy rate in this context refers to the Federal Funds Rate target, and Taylor [8] assumed that the equilibrium real interest rate $\left(r^{n}\right)$ for the US was stable around $2 \%$. The inflation gap refers to the difference between the actual inflation rate and the target inflation rate (typically, $\pi^{*}$ is assumed to be $2 \%$ ). The output gap used in Taylor's original formulation was the log difference between actual output and a linear trend output estimate. It is more common nowadays to use estimates of potential output instead of the linear trend estimate of output (Congressional Budget Office (CBO) estimates of US potential output is widely used to calculate the output gap). Taylor Rule recommends that the nominal federal funds rate target should be set such that inflation is kept near its target and output is kept as close to its potential as possible; and, second, whenever inflation exceeds its target, the nominal federal funds rate target should be raised more than one for one with inflation to bring about an increase in the real interest rate (this second feature is often referred to as the Taylor Principle).

Rate paths derived using the so-called Taylor Rule appeared to closely track the trend followed by the actual Federal Funds Rate (the primary policy interest rate targeted by the Federal Reserve) through much of the 1987-2002 period. However, according to Taylor [7] and Meltzer [25], the Federal Reserve erroneously deviated from the Taylor Rule prescribed rates between 2003 and 2005, when it decided to keep policy rates deliberately low for an extended period. Bernanke [26] has defended US central bank actions by noting that, in the early 2000s, the Federal Reserve was concerned that the American economy may fall into a deflationary trap in the aftermath of the bursting of the dotcom bubble. Persistent deflation, of course, failed to materialize and the overly accommodative policy during the period 2003-2005 (see Figure 1) possibly provided additional impetus to an already inflating US housing bubble. The real estate bubble ul- 


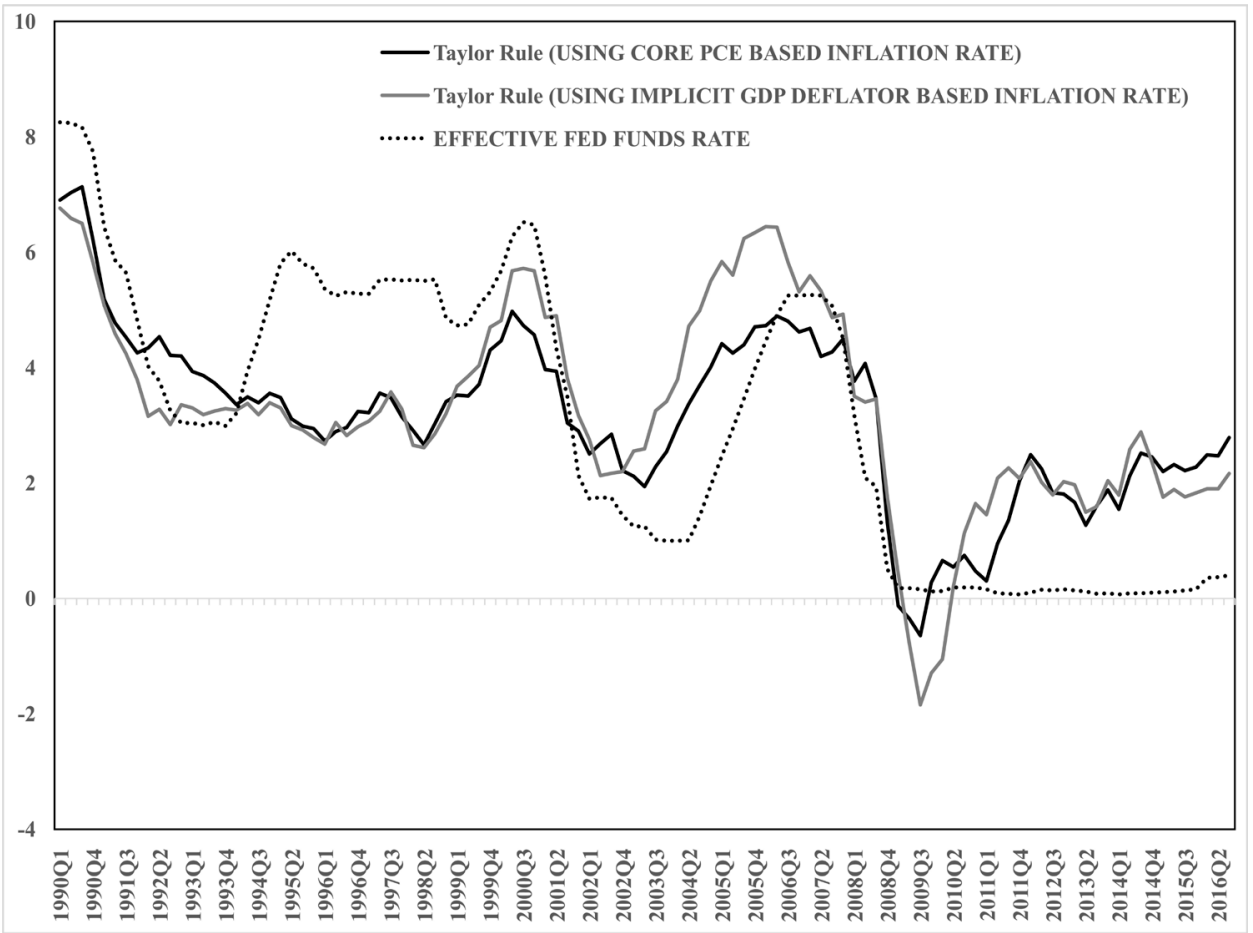

Figure 1. Effective federal funds rate (\%) and Taylor rule based interest rates (\%) using inflation rates based on core PCE and GDP deflator (Data source: federal reserve bank of Saint Louis and author's calculations).

timately burst and triggered the 2007-2009 global financial crisis. Taylor [27] has also been a vocal critic of the central bank's decision to maintain a near-zero target for the Federal Funds Rate for a prolonged period (since December 2008, the Federal Funds Rate target has remained well below $1 \%$ ). He has argued that the central bank has been led astray once gain and that the excessively accommodative post-crisis policies may lead to future financial instability.

Congressional proposals H.R. 3189: The Fed Oversight Reform and Modernization (FORM) Act of 2015 and H.R. 5983: Financial CHOICE Act of 2016 would require the Federal Reserve to formulate a monetary policy rule (referred to as "Directive Policy Rule") that clearly prescribes a formula for setting interest rates to achieve the dual mandate of price stability and maximum employment. Critically, the Congressional proposals would require the Federal Reserve to also calculate the rate based on the standard Taylor Rule (referred to as "Reference Policy Rule") and to explain any deviations between the Directive Policy Rule and the Reference Policy Rule [1]. If approved by the legislature, the Congressional proposals would essentially mandate that, in the future, the standard Taylor Rule be used as the basic guide for evaluating US central bank interest rate decisions.

There are, however, several theoretical and practical issues associated with implementing a Taylor Rule based monetary policy regime. One possible source of confusion is in regards to the choice of the underlying price index utilized to measure the inflation rate. Besides the three most widely used price indices-the implicit GDP deflator, the 
consumer price index (CPI) and the personal consumption expenditure index (PCE), there are numerous other ones that can be utilized for calculating inflation rates. The usage of headline instead of core price indices can also influence suggested interest rate paths. As shown in Figure 1, the Taylor Rule based interest rate varies noticeably when a different price index is used to calculate the inflation rate (implicit GDP deflator and core PCE index were used in this case). Taylor [8] originally used inflation rates based on the implicit GDP deflator. There is, however, no sound rationale to settle on one price index above all else. The Federal Reserve's own preferred choice of price index for calculating inflation rates has evolved over time [28]. Inflation forecasts presented by Federal Reserve members were based on the implicit GNP deflator (precursor to the implicit GDP deflator) until July 1988. Subsequently, inflation forecasts were based on headline CPI. In February 2000, the personal consumption expenditure (PCE) index became the favored measure. Starting in July 2004, Federal Reserve officials switched the basis for their inflation forecasts to core PCE index (which excludes food and energy prices).

Another practical problem related to the adoption of a Taylor Rule based policy setting framework is related to the weight placed on inflation gap stabilization vis-à-vis output gap stabilization. While Taylor [8] argued for equal weighting, Federal Reserve officials have publicly stated their preference for placing extra weight on the output gap [29]. Varying the relative weights placed on the inflation gap and the output gap does affect the policy rate prescription (see Figure 2 and note that the Taylor Rule version with greater weight placed on the output gap-weight of 1.0 on the output gap and 0.5 on the inflation gap-is referred to as the "balanced-approach rule" [29]). Complications might arise with the selection of optimal weights on the output gap and inflation gap due to structural changes in the economy.

A critical challenge with implementation of an instrument rule is the possibility of changes in the fundamental structural components included in the Taylor Rule. The post global financial crisis era has been characterized by persistently low inflation and subpar growth. This has given credence to the argument, put forth by Gordon [30] and Fernald [31], that the growth rate of potential output in the US has markedly slowed down in recent years. Demographic shifts and a slowdown in total factor productivity growth rate (and labor productivity growth rate) have affected the potential growth rate. As shown in Figure 3, the $\mathrm{CBO}$ has had to repeatedly downgrade its estimates for US potential GDP over the past decade.

Another crucial parameter in the Taylor rule-the equilibrium real interest rate (related to the Wicksellian natural rate of interest) - is also impacted by underlying structural changes in the economy. The assumption of a time-invariant equilibrium real interest rate $\left(r^{n}=2 \%\right)$, as originally recommended by Taylor [8], is questionable. Utilizing neo-classical growth theory (specifically, the Ramsey-Cass-Koopmans model [32] [33] [34]), it can be shown that the equilibrium real interest rate is determined by (see Appendix for detailed derivation of Equation (14)):

$$
r^{n}=g_{L}+\theta+\rho g_{A}
$$




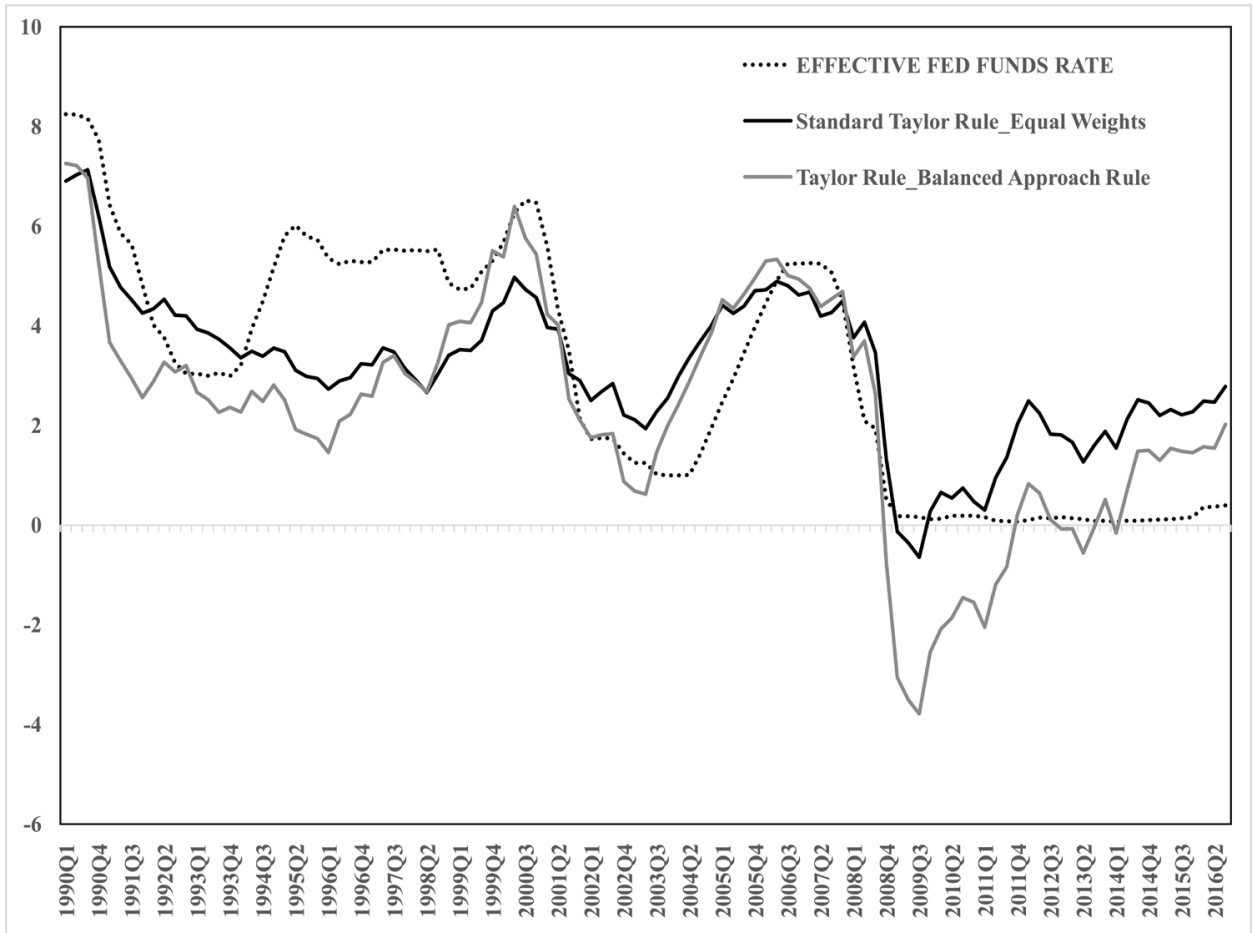

Figure 2. Effective federal funds rate (\%) and Taylor rule based interest rates (\%) - standard rule with equal weights on inflation gap and output gap and balanced approach with unequal weights on inflation gap and output gap (Data source: federal reserve bank of Saint Louis and author's calculations).

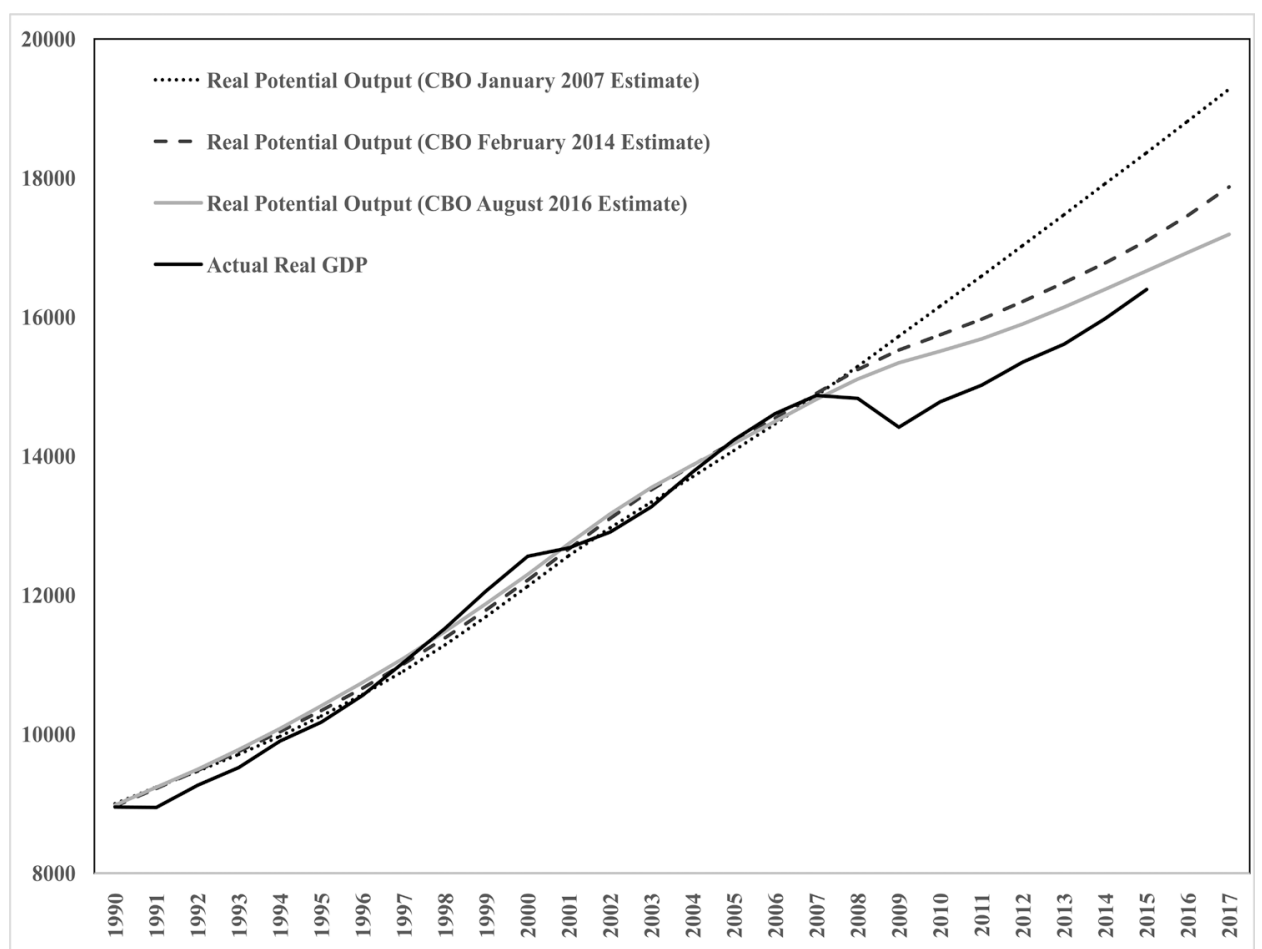

Figure 3. CBO potential GDP estimates and real GDP_constant 2009 dollars (Data source: congressional budget office and bureau of economic analysis). 
Neoclassical economic theory suggests that the equilibrium real interest rate or the natural rate of interest is dependent on economic fundamentals. Specifically, factors affecting the potential growth rate of the economy (growth rate of labor stock $\left(g_{L}=n\right)$ and pace of technological progress $\left(g_{A}=g\right)$ ) and factors affecting the saving rate of households (time preference $(\theta)$ and the intertemporal elasticity of substitution $\left.\left(\rho^{-1}\right)\right)$ are crucial. If structural changes affect these critical fundamentals, then the equilibrium real interest rate will change. Laubach and Williams [35] employed statistical filtering techniques to estimate the equilibrium real interest rate for the US economy. Their updated estimates (obtained from the Federal Reserve Bank of San Francisco website), shown in Figure 4, indicate that the equilibrium real interest rate has changed considerably over the past decade.

Continued usage of a constant equilibrium real interest rate (generally set equal to $2 \%$, following Taylor [8]) may result in erroneous recommendations for setting policy rates. The Laubach-Williams estimation of the equilibrium real interest rate has consistently remained below $2 \%$ since the onset of the Great Recession. Incorporating the lower estimated values for equilibrium real interest rate implies a Taylor Rule rate path that differs markedly from one based on an invariant $2 \%$ equilibrium real interest rate assumption. As shown in Figure 5, the Federal Reserve's post-crisis policy approach is vindicated if we account for the structural changes buffeting the American economy (decline in the estimates of US potential output as well as the fall in the equilibrium real interest rate). Maintaining low interest rates for an extended period and undertaking unconventional monetary policy actions may, in fact, turn out to have been the right

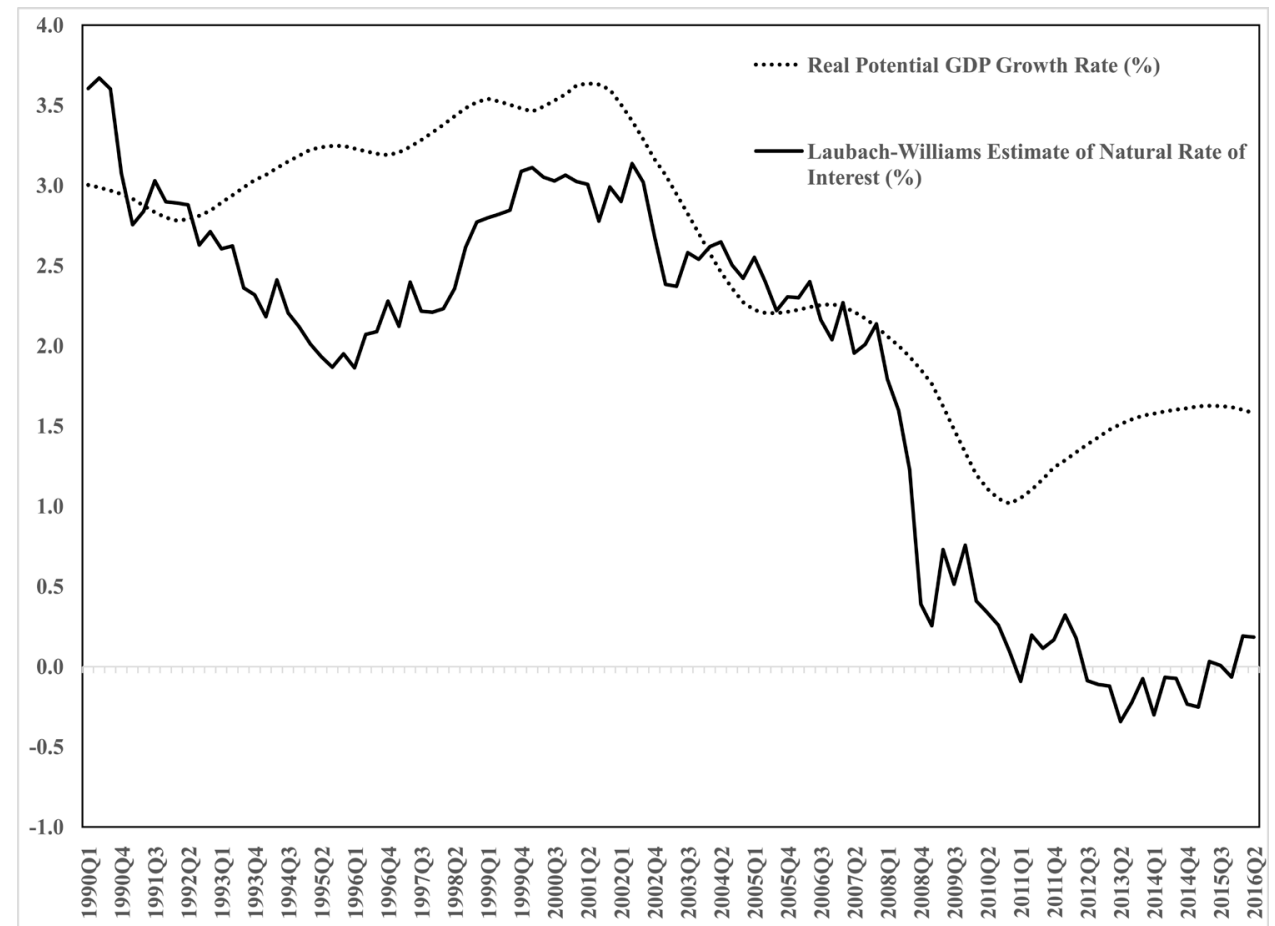

Figure 4. Potential output growth rate and natural rate of interest (\%) (Data source: CBO and federal reserve bank of San Francisco). 


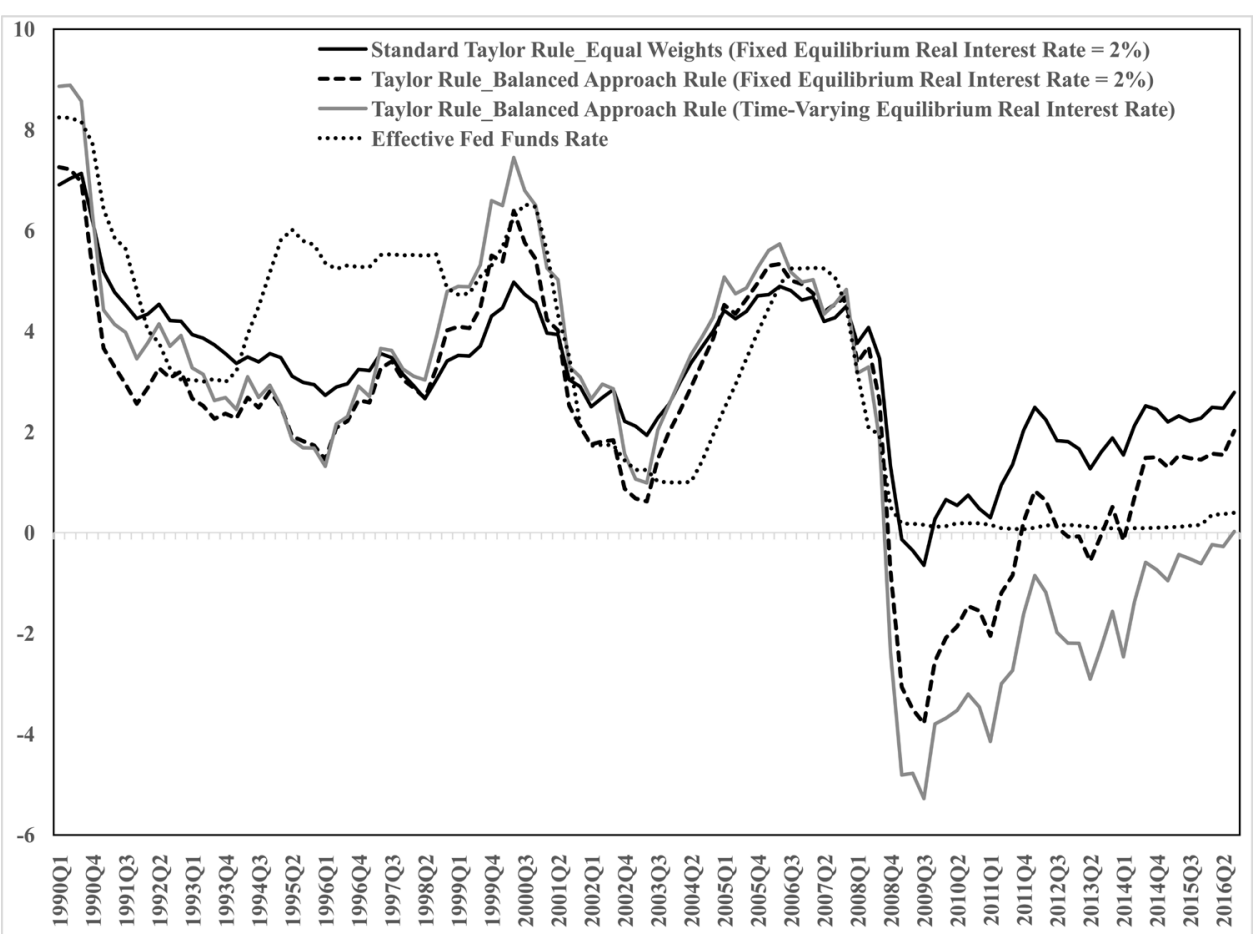

Figure 5. Taylor rule based interest rates (\%)-fixed versus time-varying equilibrium real interest rates (Data source: federal reserve bank of St. Louis, federal reserve bank of san Francisco and author's calculations).

policy choices for the post-crisis era.

A difficult challenge in mechanically using simple policy rate setting rules to conduct monetary policy is that current central bank actions typically affect the future direction of the economy. The inherently forward-looking nature of policy interest rate setting implies some degree of built in uncertainty. In recent years, economists [36] have modified the Taylor Rule framework to incorporate future inflation forecasts and estimates of current and future output gaps, which are typically obtained from surveys of professional forecasters and from Federal Reserve's own models. Despite technical improvements, economic forecasting remains an imperfect science. Unpredictable domestic and international financial market shocks as well as political surprises can derail even the best economic forecasts. Furthermore, when the zero lower bound (ZLB) (or more accurately, the effective lower bound) is reached in regards to nominal policy rates, the efficacy of utilizing the standard Taylor Rule for monetary policymaking becomes questionable ([9] [37]). If monetary authorities had remained wedded solely to a single policy instrument (short-term interest rate), they would have been severely handicapped in dealing with the economic and financial challenges that arose during and after the recent financial crisis. Events since 2007 have clearly highlighted the necessity of a well-stocked and flexible monetary policy toolkit-quantitative easing and forward guidance were the primary monetary policy instruments employed in the post-crisis period by the Federal Reserve, the European Central Bank, Bank of Japan and Bank of England. 
Given all the above noted flaws, it will be imprudent to legislate that monetary authorities follow a simple operations mandate regime based on the standard Taylor Rule. Strict adherence to mechanical interest rate setting rules may be too limiting in a world where the underlying economic structure is evolving due to demographic and technological shifts. Additionally, the absence of financial stability related variables in the standard Taylor Rule is a cause for concern in the post-financial crisis era. There, however, does exist a rationale for constricting the goals of monetary policy-narrowing the focus of central bankers towards a clearly defined medium term goal would still be a worthwhile legislative endeavor as discussed in the next section.

\section{Goal Mandate/Targeting Rule-A Superior Alternative to Taylor Rule Type Instrument Rule/Operation Mandate}

Ever since the collapse of the Bretton Woods System in the early 1970s, monetary economists have been seeking an appropriate nominal anchor to achieve macroeconomic stability. Following brief flirtations with monetary aggregate targeting and exchange rate targeting, the consensus view appeared to settle on inflation targeting as a reasonable anchor for central banks. From a theoretical standpoint, as well, it has been argued in recent decades that independent central banks need to be constrained via the establishment of a clearly defined goal mandate or targeting rule. A targeting rule/goal mandate that is tied to central bank transparency is assumed to be superior to any instrument rule/operational mandate [12] [13] [38]. Woodford ([13], p. 35) succinctly summarizes the case for a monetary policymaking regime centered on a targeting rule: "The organization of the decision process around the achievement of an explicit, quantitative target that is also communicated to the public, and a commitment to the explanation of policy decisions to the public in terms that allow verification of the central bank's commitment to its putative target are important improvements upon prior procedures. They can both help to safeguard a central bank against the trap of discretionary policymaking, and help the private sector to more accurately anticipate future policy, increasing the effectiveness of policy. The introduction of targeting rules as a way of specifying policy commitments is also an important conceptual advance, allowing commitments to be stated in a way that incorporates a kind of flexibility that is of considerable practical value, while being specific about the aspects of policy that are most critical for anchoring private sector expectations".

Since 1990, the most popular form of targeting rule has been the inflation targeting regime [39] [40], where a central bank shoulders the responsibility for keeping inflation, on average, near a publicly announced target (decided in consultation with the government). Around 26 countries-both advanced and emerging economies-currently pursue some form of an inflation-targeting monetary regime [41]. However, since 2008, there has been a growing chorus of criticism directed at inflation targeting regimes. It has been argued that central banks relying on inflation targeting failed to pay attention to asset price bubbles, whose sudden deflation had devastating consequences for the global economy. It has also been noted that inflation targeting regimes 
suffer from another fundamental weakness-they often respond inappropriately to supply shocks and to significant terms of trade effects. Higher global commodity prices often force central banks in commodity importing countries to aggressively tighten policy instead of accommodating the term of trade shock caused by external forces [18]. Positive supply shocks are also dealt with inadequately-muted reaction to rapid economic growth accompanied by low inflation is often the norm.

Rising criticism of inflation targeting regimes, has led to a search for alternatives. Other widely discussed possibilities for a targeting rule/goal mandate based monetary regime include price-level targeting and nominal GDP targeting. Under price-level targeting, keeping the economy on a chosen optimal path for price level growth over time is the central bank's primary objective. Note that with price-level targeting, unlike inflation targeting, periods of above trend inflation must be offset by periods of below trend inflation to keep the price-level path stable [42] [43]. In the case of nominal GDP (NGDP) targeting, a central bank would choose a target path for NGDP (or a target growth rate for NGDP). Policy rates would be set in a manner that is consistent with reaching the nominal GDP target over the medium run [18]. Given that NGDP incorporates real output changes and price level changes, targeting it would be consistent with Federal Reserve's existing dual mandate (price stability and full employment). Table 1 summarizes the advantages and disadvantages of the three leading targeting rule contenders [44]. Possible modifications to improve the simple versions of the three major targeting rules are also noted.

While inflation targeting and price-level targeting have their advantages, their actual or perceived inability to deal with asset price bubbles and with productivity or terms of trade related shocks is a critical drawback. Support is building for NGDP targeting, especially given the weak and fitful post-crisis economic recovery in advanced economies. NGDP targeting places greater emphasis on eliminating persistent deviations of output from its target path compared to a pure inflation targeting regime. It also places greater weight on output gaps than the standard Taylor Rule framework. A sharp recession can be dealt with more easily in a NGDP targeting regime-when faced with a significant aggregate demand shortfall and persistently low inflation, NGDP targeting will place more weight than an inflation targeting or a standard Taylor rule based regime on restoring real output to its potential [18].

NGDP targeting is also theoretically better suited to deal with supply shocks. A positive supply shock typically lowers prices while boosting output-the NGDP targeting regime would call for a limited policy response as the two effects largely offset each other. However, under an inflation targeting or price-level targeting regime, lower interest rates would be called for in response to the disinflation. Low rates would fuel output growth further and potentially lead to excessive investment and/or asset bubbles. In the case of an adverse supply shock, NGDP targeting would again perform better than the alternatives. Since the effects will be split between inflation and real GDP, there is limited need for an aggressive policy response [18].

Given recent events, it is worth highlighting an important potential advantage of 
Table 1. Advantages and disadvantages of three major goal mandate (targeting rule) regimes [18] [44].

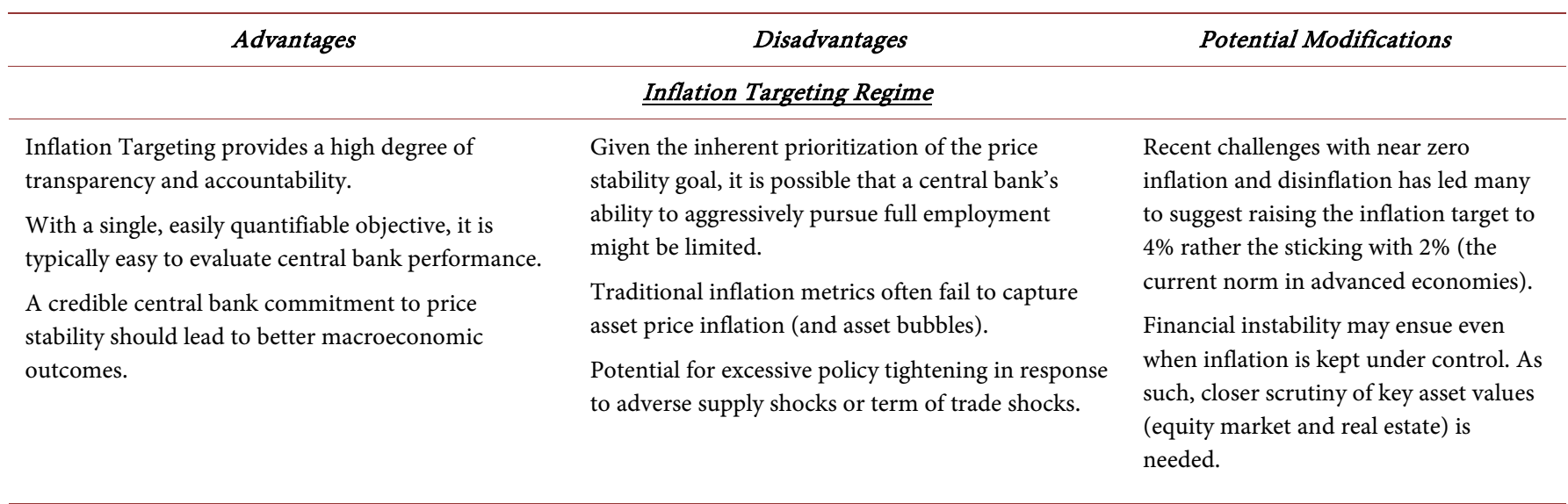

\section{Price-Level Targeting Regime}

The advantages noted above for inflation targeting also apply to price-level targeting.

Inflationary shocks do not lead to a permanent shift in price-level paths.

In case of negative demand shocks (reduction in output and decline in inflation), central banks can pursue full-employment more aggressively.
Adverse supply shocks can be problematic if strict adherence to price-level targeting is expectedcentral banks would be forced to tighten monetary policy aggressively to fight rising prices.

Returning the economy to the designated price level path after even a temporary supply shock may require sharp monetary tightening to offset initial above trend inflation.
As suggested by Hall [45] and Ball et al. [46], an "elastic" price-level targeting system that allows the price-level target to depend on labor market conditions (unemployment rate) may be superior to a strict price-level targeting regime.

\section{Nominal GDP Targeting Regime}

The advantages noted above for inflation targeting also apply to NGDP targeting.

NGDP targeting focuses on stabilizing aggregate demand-an appropriate goal for monetary policy. NGDP targeting may be more effective at attaining full employment-central banks have more room to maneuver. When faced with an effective lower bound (or ZLB) situation, it might be easier to raise inflation expectations under NGDP targeting.

Supply shocks are automatically split between inflation and real GDP, which eases the policy response burden significantly.
Central banks might find it hard to stick to NGDP targeting if inflation spikes sharply.

Structural changes to the economy may affect potential output and consequently the sustainable real GDP levels.

Data on inflation, unlike real output, are available at higher frequencies and subject to fewer revisions.
Sumner [47] suggests a futures contract approach-monetary policy should respond to expected future NGDP instead of current NGDP. This could help overcome an inherent drawbackNGDP responds rather slowly to monetary policy.

NGDP targeting-its ability to moderate the boom-bust cycles afflicting asset prices. Asset bubbles tend to originate during periods when output growth exceeds potential and when credit constraints are eased. Because NGDP targeting would raise interest rates during periods of strong growth (even when inflation remains subdued) and economic euphoria, it is likely to moderate the pro-cyclicality of credit cycles and thus limit asset price volatility. Low interest rate and low inflation environments, in combination with excessive credit growth, have proven to be conducive for the formation of asset bubbles. NGDP targeting, by broadening the focus of monetary policymakers beyond inflation, can potentially limit the size and frequency of asset bubbles.

Based on the above noted characteristics of the various goal mandate/targeting rule 
regimes, it is apparent that a NGDP targeting framework would be preferable to a Taylor Rule type instrument rule/operational mandate regime. The ability to achieve transparency, accountability and central bank credibility while still retaining a reasonable degree of operational flexibility is the hallmark of a well-designed targeting rule based monetary regime.

\section{Conclusions}

The push by Congressional leaders to bring forth greater transparency and clarity to US monetary policymaking should be applauded. However, legislative proposals that aim to impose an instrumental rule regime requiring a strict adherence to an interest rate setting rule appear to be misguided. Pushing through proposals whose central aim is to require the Federal Reserve to formulate and implement simple monetary rules tied to the Taylor Rule is imprudent. As highlighted in this study, there are numerous problems-measurement and data selection issues, structural parameter changes and inability to deal with severe economic shocks (due to nominal interest rates facing a lower bound)-that will impede both the implementation as well as the operational effectiveness of a simple Taylor Rule based monetary regime. The sensitivity of Taylor Rule to the choice of price level indices and to the relative weights placed on inflation gap vis-à-vis output gap is problematic. More importantly, this study shows that underlying structural changes in the economy will impact the two structural components central to the Taylor Rule. In other words, equilibrium real interest rate and potential output are not time-invariant, and this affects the consistency of the rate path provided by the standard Taylor Rule. Over the past decade and a half, lower productivity growth in combination with slower growth in the labor force has pushed down equilibrium real interest rate and potential output growth rates in the US. Failure to account for such fundamental changes in a standard Taylor Rule setup is a serious drawback.

In the aftermath of the recent financial crisis, it has also become apparent that central banks need to have an expansive monetary toolkit and attempts to regulate or restrict the operational freedom of monetary authorities will likely prove to be counterproductive. Federal Reserve, the European Central Bank, Bank of Japan and Bank of England have all relied on unconventional monetary policy tools in recent years to deal with persistently low inflation and subpar economic growth.

Empirical and theoretical research clearly suggest that a targeting rule regime, which maintains operational freedom but narrows the overall goals of central banks, is generally superior to an instrument rule regime. Maintaining flexibility while still enabling the establishment of a transparent, credible and accountable central bank is feasible under a targeting rule based monetary regime. Selection of an appropriate targeting rule is an important decision for political leaders and central bankers. An evaluation of the advantages and disadvantages of the three primary options-inflation targeting, price-level targeting and NGDP targeting, indicates that targeting of nominal GDP provides the right balance between output/employment concerns and price stability concerns. In theory, NGDP targeting should be better suited to dealing with aggregate 
demand and aggregate supply shocks. It also may be more effective at moderating asset boom-bust cycles. For the US, NGDP targeting regime might be more palatable given that the Federal Reserve currently operates under a dual mandate (the 1977 amendment to the Federal Reserve states: "The Board of Governors of the Federal Reserve System and the Federal Open Market Committee shall maintain long run growth of the monetary and credit aggregates commensurate with the economy's long run potential to increase production, so as to promote effectively the goals of maximum employment, stable prices and moderate long-term interest rates").

Overall, this study emphasizes the basic flaw in proposed legislation aimed at instituting a highly restrictive monetary rule regime in the US. The standard Taylor Rule, despite being a useful guidepost for central bankers, has far too many shortcomings and is a poor basis for an instrument rule/operational mandate based monetary regime. Additionally, as argued in the article, a targeting rule/goal mandate is likely to be a superior option for designing a monetary regime. For instance, a well-designed NGDP targeting regime might bring more clarity and transparency to the existing Federal Reserve mandate, without sacrificing the central bank's operational freedom, and potentially help reduce the uncertainty associated with the future interest rate path.

\section{Acknowledgements}

The author wishes to thank the anonymous referee for suggestions that improved the structure of the paper.

\section{References}

[1] Labonte, M. (2016) Federal Reserve: Legislation in the 114th Congress. Congressional Research Service Report R44273, Washington DC.

[2] Hensarling, J. (2015) Reining in a Sprawling Federal Reserve. Wall Street Journal. http://www.wsj.com/articles/reining-in-a-sprawling-federal-reserve-1447978230

[3] Debelle, G. and Fischer, S. (1994) How Independent Should a Central Bank Be? In: Fuhrer, C., Ed., Goals, Guidelines, and Constraints Facing Monetary Policymakers, Federal Reserve Bank of Boston, Boston, 195-221.

[4] Fischer, S. (2015) Central Bank Independence. Speech at the 2015 Herbert Stein Memorial Lecture National Economists Club, Washington DC.

https://www.federalreserve.gov/newsevents/speech/fischer20151104a.htm

[5] Kydland, F.E. and Prescott, E.C. (1977) Rules Rather than Discretion: The Inconsistency of Optimal Plans. Journal of Political Economy, 85, 473-491. https://doi.org/10.1086/260580

[6] Barro, R.J. and Gordon, D.B. (1983) A Positive Theory of Monetary Policy in a Natural Rate Model. Journal of Political Economy, 91, 589-610. https://doi.org/10.1086/261167

[7] Taylor, J.B. (2012) Monetary Policy Rules Work and Discretion Doesn't: A Tale of Two Eras. Journal of Money, Credit, and Banking, 44, 1017-1032. https://doi.org/10.1111/j.1538-4616.2012.00521.x

[8] Taylor, J.B. (1993) Discretion versus Policy Rules in Practice. Carnegie Rochester Conference Series on Public Policy, 39, 195-214. https://doi.org/10.1016/0167-2231(93)90009-L

[9] Bernanke, B.S. (2015) The Taylor Rule: A Benchmark for Monetary Policy? Brookings Institution. 
http://www.brookings.edu/blogs/ben-bernanke/posts/2015/04/28-taylor-rule-monetary-pol icy

[10] Yellen, J. (2015) Letter to Honorable Paul Ryan and Honorable Nancy Pelosi. https://www.federalreserve.gov/foia/readingrooms.htm\#congcomm

[11] Blinder, A.S. (2014) An Unnecessary Fix for the Fed. Wall Street Journal. http://www.wsj.com/articles/alan-s-blinder-an-unnecessary-fix-for-the-fed-1405639582

[12] Williams, J.C. (2015) Monetary Policy and the Independence Dilemma. FRB San Francisco Working Paper 2015-15.

[13] Svensson, L.E.O. (2003) What Is Wrong with Taylor Rules? Using Judgment in Monetary Policy through Targeting Rules. Journal of Economic Literature, 41, 426-477. https://doi.org/10.1257/.41.2.426

[14] Woodford, M. (2004) Inflation Targeting and Optimal Monetary Policy. Federal Reserve Bank of St. Louis Review, 86, 15-41.

[15] McCallum, B.T. and Nelson, E. (2005) Targeting vs. Instrument Rules for Monetary Policy. Federal Reserve Bank of St. Louis Review, 87, 597-611.

[16] Wicksell, K. (1936) Interest and Prices: A Study of the Causes Regulating the Value of Money. Macmillan, London.

[17] Hayek, F.A. (1984) Money, Capital and Fluctuations: Early Essays. University of Chicago Press, Chicago. https://doi.org/10.7208/chicago/9780226321271.001.0001

[18] Sumner, S. (2014) Nominal GDP Targeting: A Simple Rule to Improve Fed Performance. Cato Journal, 34, 315-337.

[19] White L.H. (1999) Hayek's Monetary Theory and Policy: A Critical Reconstruction. Journal of Money, Credit, and Banking, 31, 109-120. https://doi.org/10.2307/2601142

[20] Friedman, M. (1960) A Program for Monetary Stability. Fordham University Press, New York.

[21] Woodford, M. (2003) Interest and Prices: Foundations of a Theory of Monetary Policy. Princeton University Press, Princeton.

[22] Svensson, L.E.O. (1999) Inflation Targeting as Monetary Policy Rule. Journal of Monetary Economics, 43, 607-654. https://doi.org/10.1016/S0304-3932(99)00007-0

[23] Rotemberg, J.J. and Woodford, M. (1999) Interest Rate Rules in an Estimated Sticky Price Model. In: Taylor, J.B., Ed., Monetary Policy Rules, University of Chicago Press, Chicago, 57-119.

[24] Taylor, J.B. (1999) A Historical Analysis of Monetary Policy Rules. In: Taylor, J.B., Ed., Monetary Policy Rules, University of Chicago Press, Chicago, 319-348. https://doi.org/10.7208/chicago/9780226791265.001.0001

[25] Meltzer, A.H. (2011) Politics and the Fed. Journal of Monetary Economics, 58, 39-48. https://doi.org/10.1016/j.jmoneco.2010.09.009

[26] Bernanke, B.S. (2010) Monetary Policy and the Housing Bubble. Speech at the Annual Meeting of the American Economic Association, Atlanta, Georgia. https://www.federalreserve.gov/newsevents/speech/bernanke20100103a.htm

[27] Taylor, J.B. (2014) Re-Normalize, Don't New-Normalize Monetary Policy. Macroeconomic Review, 13, 86-90.

[28] Mehra, Y.P. and Sawhney, B. (2010) Inflation Measure, Taylor Rules, and the GreenspanBernanke Years. Economic Quarterly, 96, 123-151.

[29] Yellen, J. (2012) Perspectives on Monetary Policy. Speech at the Boston Economic Club 
Dinner, Boston, Massachusetts.

https://www.federalreserve.gov/newsevents/speech/yellen20120606a.htm

[30] Gordon, R. (2016) The Rise and Fall of American Growth: The US Standard of Living since the Civil War. Princeton University Press, Princeton.

https://doi.org/10.1515/9781400873302

[31] Fernald, J.G. (2016) Reassessing Longer-Run US Growth: How Low? FRB San Francisco Working Paper 2016-18.

[32] Ramsey, F. (1928) A Mathematical Theory of Saving. Economic Journal, 38, 543-559. https://doi.org/10.2307/2224098

[33] Cass, D. (1965) Optimum Growth in an Aggregative Model of Capital Accumulation. Review of Economic Studies, 32, 233-240. https://doi.org/10.2307/2295827

[34] Koopmans, T.C. (1965) On the Concept of Optimal Economic Growth. In: Study Week on the Econometric Approach to Development Planning, North-Holland Publishing Co., Amsterdam, Chap. 4, 225-287.

[35] Laubach, T. and Williams, J.C. (2003) Measuring the Natural Rate of Interest. Review of Economics and Statistics, 85, 1063-1070. https://doi.org/10.1162/003465303772815934

[36] Levin, A.T., Wieland, V. and Williams, J.C. (2003) The Performance of Forecast-Based Monetary Policy Rules under Model Uncertainty. American Economic Review, 93, 622-645. https://doi.org/10.1257/000282803322157016

[37] Rudebusch, G.D. (2009) The Fed's Monetary Policy Response to the Current Crisis. FRBSF Economic Letter 2009-17.

[38] Svensson, L.E.O. (2005) Targeting versus Instrument Rules for Monetary Policy: What Is Wrong with McCallum and Nelson. Federal Reserve Bank of St. Louis Review, 87, 613-625.

[39] Bernanke, B.S. and Mishkin, F.S. (1997) Inflation Targeting: A New Framework for Monetary Policy? Journal of Economic Perspectives, 11, 97-116. https://doi.org/10.1257/jep.11.2.97

[40] Bernanke, B.S., Laubach, T., Mishkin, F.S. and Posen, A.S. (1999) Inflation Targeting: Lessons from the International Experience. Princeton University Press, Princeton.

[41] Scott, R. (2010) Inflation Targeting Turns 20. Finance \& Development, 47, 46-49.

[42] Svensson, L.E.O. (1999) Price-Level Targeting versus Inflation Targeting: A Free Lunch? Journal of Money, Credit, and Banking, 31, 277-295. https://doi.org/10.2307/2601112

[43] Ambler, S. (2009) Price-Level Targeting and Stabilization Policy: A Review. Bank of Canada Review, 19-29.

[44] Binder, C. and Rodrigue, A. (2016) Monetary Rules and Targets: Finding the Best Path to Full Employment. Center on Budget and Policy Priorities Working Paper, Washington DC.

[45] Hall, R. (1985) Monetary Strategy with an Elastic Price Standard. Paper Presented at the Symposium, Price Stability and Public Policy, Federal Reserve Bank of Kansas City.

[46] Ball L.N., Mankiw, G. and Reis, R. (2005) Monetary Policy for Inattentive Economies. Journal of Monetary Economics, 52, 703-725. https://doi.org/10.1016/j.jmoneco.2005.03.002

[47] Sumner, S. (2015) Nominal GDP Futures Targeting. Journal of Financial Stability, 17, 6575. https://doi.org/10.1016/j.jfs.2014.10.001 


\section{Appendix: Neoclassical Theories and the Equilibrium Real Interest Rate}

Traditional growth models offer a useful starting point for considering potential drivers of equilibrium interest rates. Exogenous growth models of the Ramsey-Cass-Koopmans [32] [33] [34] variety are especially useful for analyzing the theoretical determinants of equilibrium real interest rates. The canonical model of optimal growth for an economy characterized by exogenous labor-augmenting technological progress and exogenous population growth is described below.

The production side of the model can be represented with a standard Cobb-Douglas production function:

$$
Y=F(K, L)=K^{\alpha}(A L)^{1-\alpha}
$$

Assume that the labor supply (and the population) increases at an exogenous rate $n$ :

$$
L=L_{0} \mathrm{e}^{n t}
$$

Also, labor-augmenting technological progress is assumed to take place at an exogenously determined rate $g$ :

$$
A=A_{0} \mathrm{e}^{g t}
$$

Net investment equals gross investment minus depreciation:

$$
\dot{K}=I-\delta K=Y-C-\delta K
$$

Dividing both sides of the production function by $A L$ allows us to consider the production function in terms of efficiency units (define capital per effective worker as $k=K / A L$, consumption per effective worker as $c=C / A L$ and output per effective worker as $y=Y / A L)$ :

$$
Y / A L=K^{\alpha}(A L)^{1-\alpha} / A L \Rightarrow y=f(k)=k^{\alpha}
$$

To obtain the law of motion of capital per effective worker, note that (the standard notation for time derivatives-a dot on top of the variable-is employed throughout this article):

$$
\begin{gathered}
\dot{k}=\mathrm{d} k / \mathrm{d} t=[\dot{K} A L-K(\dot{A} L-A \dot{L})] /(A L)^{2}=\dot{K} / A L-k(\dot{A} / A+\dot{L} / L) \\
\dot{k}=\dot{K} / A L-k(g+n)
\end{gathered}
$$

Combining (A.4) and (A.7) yields:

$$
\dot{k}=f(k)-c-(n+g+\delta) k
$$

The social planner's objective can be described as the maximization of the discounted social utility function that depends on the infinite-horizon per-capita consumption (in our case, consumption per effective worker):

$$
\max U=\int_{0}^{\infty} u(c) \mathrm{e}^{-\theta t} \mathrm{~d} t
$$

Subject to $\dot{k}=f(k)-c-(n+g+\delta) k$.

Here $c$ refers to consumption per effective worker; $u$ is the utility function; and 
$\theta$ is the discount factor.

The Hamiltonian is given by:

$$
\mathcal{H}=u(c) \mathrm{e}^{-\theta t}+\mu[f(k)-c-(n+g+\delta) k]
$$

The optimality conditions are:

$$
\begin{gathered}
\partial \mathcal{H} / \partial c=u^{\prime}(c) \mathrm{e}^{-\theta t}-\mu=0 \\
\partial \mathcal{H} / \partial k=\mu\left[f^{\prime}(k)-(n+g+\delta)\right]=-\mu^{\prime}
\end{gathered}
$$

Suppose that $\lambda=\mu \mathrm{e}^{\theta t}$. The optimality conditions can then be rewritten as follows:

$$
\begin{gathered}
\lambda \mathrm{e}^{-\theta t}=u^{\prime}(c) \mathrm{e}^{-\theta t} \Rightarrow u^{\prime}(c)=\lambda \\
\mu^{\prime}=\lambda^{\prime} \mathrm{e}^{-\theta t}-\theta \lambda \mathrm{e}^{-\theta t}=\lambda \mathrm{e}^{-\theta t}\left[(n+g+\delta)-f^{\prime}(k)\right]
\end{gathered}
$$

Equation (A.14) can be restated as:

$$
\lambda^{\prime}=\lambda\left[(n+g+\delta)+\theta-f^{\prime}(k)\right]
$$

Combining (A.13) and (A.15), and noting that $\lambda^{\prime}=u^{\prime \prime}(c) \frac{\mathrm{d} c}{\mathrm{~d} t}$ yields:

$$
\frac{\lambda^{\prime}}{\lambda}=\frac{u^{\prime \prime}(c)}{u^{\prime}(c)} \frac{\mathrm{d} c}{\mathrm{~d} t}=\left[(n+g+\delta+\theta)-f^{\prime}(k)\right]
$$

Consider an isoelastic utility function (note: $\rho$ represents the degree of relative risk aversion and hence $1 / \rho$ is the intertemporal elasticity of substitution):

$$
u(c)=(C / L)^{1-\rho} / 1-\rho
$$

To restate in terms of consumption per effective worker, note the following (recall that labor-augmenting technological progress is assumed to occur at the exogenous rate $g$ (see Equation (A.3)):

$$
C / L=A(C / A L)=A c=c A_{0} \mathrm{e}^{g t}
$$

Therefore, the isoelastic utility function can be rewritten as:

$$
u(c)=(C / L)^{1-\rho} / 1-\rho=\left(c A_{0} \mathrm{e}^{g t}\right)^{1-\rho} / 1-\rho=A_{0}\left[c^{1-\rho} / 1-\rho\right] \mathrm{e}^{(1-\rho) g t}
$$

The social planner's problem with the isoelastic utility function is thus given by (after normalizing initial level of technology, $A_{0}=1$ and letting $\left.\sigma=\theta-(1-\rho) g\right)$ :

$$
\max U=\int_{0}^{\infty} u(c) \mathrm{e}^{-\theta t} \mathrm{~d} t=\int_{0}^{\infty}\left[c^{1-\rho} / 1-\rho\right] \mathrm{e}^{-\sigma t} \mathrm{~d} t
$$

Subject to $\dot{k}=f(k)-c-(n+g+\delta) k$

Define:

$$
v(c)=c^{1-\rho} / 1-\rho
$$

Now, the social planner's problem can be reformulated in a form similar to that in Equation (A.9): 


$$
\max U=\int_{0}^{\infty} v(c) \mathrm{e}^{-\sigma t} \mathrm{~d} t
$$

Subject to $\dot{k}=f(k)-c-(n+g+\delta) k$

With the isoelastic utility function, we can rewrite our optimality condition (A.16) as follows:

$$
\frac{v^{\prime \prime}(c)}{v^{\prime}(c)} \frac{\mathrm{d} c}{\mathrm{~d} t}=\frac{-\rho c^{-\rho-1}}{c^{-\rho}} \frac{\mathrm{d} c}{\mathrm{~d} t}=-\rho \frac{\dot{c}}{c}=\left[(n+g+\delta+\sigma)-f^{\prime}(k)\right]
$$

Substituting $\sigma=\theta-(1-\rho) g$, we get:

$$
\frac{\dot{c}}{c}=\frac{1}{\rho}\left[(n+g+\delta+\theta-(1-\rho) g)-f^{\prime}(k)\right]
$$

In steady-state,

$$
\frac{\dot{c}}{c}=0 \Rightarrow f^{\prime}(k)-\delta=n+\theta+\rho g
$$

The equilibrium real interest rate is given by:

$$
r^{n}=f^{\prime}(k)-\delta=n+\theta+\rho g
$$

\section{Submit or recommend next manuscript to SCIRP and we will provide best service} for you:

Accepting pre-submission inquiries through Email, Facebook, LinkedIn, Twitter, etc. A wide selection of journals (inclusive of 9 subjects, more than 200 journals)

Providing 24-hour high-quality service

User-friendly online submission system

Fair and swift peer-review system

Efficient typesetting and proofreading procedure

Display of the result of downloads and visits, as well as the number of cited articles

Maximum dissemination of your research work

Submit your manuscript at: http://papersubmission.scirp.org/

Or contact tel@scirp.org 